Article

\title{
Estimating the Potential for Forest Degradation in the Eastern United States Woodlands from an Introduction of Sudden Oak Death
}

\author{
Dillon J. Haller * and Michael C. Wimberly \\ Department of Geography and Environmental Sustainability, University of Oklahoma, Norman, OK 73019, USA; \\ mcwimberly@ou.edu \\ * Correspondence: Dillon.J.Haller-1@ou.edu
}

Received: 13 November 2020; Accepted: 12 December 2020; Published: 15 December 2020

\begin{abstract}
Research Highlights: This research identified areas of the eastern United States forests that may be at particular risk from Sudden Oak Death (SOD) if it becomes established in the region. The highest suitability for SOD occurs where there are both species at risk of serious infection and species that could spread SOD to new hosts. Background and Objectives: SOD, caused by Phytophthora ramorum, can cause serious damage to forests. Although SOD is not believed to exist in the wild in the eastern United States, the presence of potential P. ramorum hosts in the area has led to questions about the potential for its establishment there. The present project expanded on previous efforts by examining both the possibility and potential consequences of $P$. ramorum establishment based on the presence of suitable hosts. Materials and Methods: We developed a map of the potential severity of tree loss that could result from a P. ramorum establishment in the eastern United States as well as a habitat suitability index based on the density of $P$. ramorum susceptible and spreader host species. We also implemented a connectivity analysis method for determining patches important to the spread of P. ramorum in the Great Smoky Mountains National Park. Results: The Ozarks and Appalachians both had a high potential severity of infection due to their high percentage of susceptible species, but the Appalachians had a higher overall level of risk due to the presence of more spreader tree species in the area. Connectivity analysis in the Great Smoky Mountains National Park identified patches likely to be particularly important to P. ramorum spread. Conclusions: Analysis of the presence of potential P. ramorum hosts in the eastern United States identified suitable conditions for SOD establishment there, particularly in the Appalachians. Techniques developed in this research can identify critical areas for SOD spread at both landscape and regional scales.
\end{abstract}

Keywords: Sudden Oak Death; Phytophthora ramorum; forest epidemiology; eastern United States forests; oaks

\section{Introduction}

\subsection{Sudden Oak Death Characteristics}

Sudden Oak Death (SOD) is a recently established destructive tree disease that first appeared in the forests of California in 1995 and began rapidly spreading thereafter [1,2]. The disease is caused by an oomycete called Phytophthora ramorum. SOD affects oaks (Quercus spp.) and tanoaks (Notholithocarpus densiflorus), though P. ramorum can infect a wide variety of botanical hosts and cause a wide range of conditions. Despite the name, trees that develop SOD may not die for years after initial symptoms present themselves, though in some cases, SOD can kill more quickly. Seedlings and saplings are rarely affected by SOD [1]. 
Field studies suggest that a susceptible oak within range of a P. ramorum infection has a $4-5 \%$ yearly chance of becoming infected. Trees that are infected and showing symptoms (e.g., bleeding) typically have a median survival time of 6-10 years, depending on the species [3]. Among tanoaks, infection probability is even higher (around 10\% yearly) and survival time even lower (median less than six years) than among true oaks [3]. All available data suggest that among oaks, red oak types (Quercus s. Lobatae) are at considerable risk, while white oaks (Quercus s. Quercus) are not particularly susceptible [4]. As multiple species of red oaks are widespread in the forests of the eastern United States, there is substantial concern about the possibility of $P$. ramorum establishment in this region.

$P$. ramorum does not only infect oaks and their relatives; it is known to infect a range of hosts including trees like maples (Acer spp.), Douglas-fir (Pseudotsuga menziesii), and California bay laurel (Umbellularia californica) as well as shrubs like Rhododendron spp., Viburnum spp., and honeysuckle (Lonicera hispidula). In these hosts, the pathogen has significantly less deleterious effects, and the disease it causes is known as ramorum leaf blight or ramorum shoot dieback, after the main symptoms. While these hosts are at less risk, infections in them are ecologically significant because they may transmit the pathogen to more susceptible individuals. To assess the potential impacts of SOD in the eastern United States, it is essential to consider the distributions of susceptible oaks as well as those of spreader species.

Interestingly, while red oaks are highly susceptible to the pathogen, they do not appear to be capable of transmitting it onward [4]. Tanoaks, however, are both susceptible to SOD and capable of passing P. ramorum on to new hosts [4]. A possible strategy for the control of the spread of SOD is to thin out less affected spreader species in the forests, an idea supported by modeling studies [5].

\subsection{Sudden Oak Death Range Prediction}

Until 2016, P. ramorum was only known to be established in the wild in the western U.S., mainly in the coastal regions of California and the far southwestern corner of Oregon. The pathogen has also been found in the Sierra Nevada, though it does not yet appear to be widespread in this area [6]. In 2016, the pathogen was also found in Southeast Asia, but its activity there is not well studied [7]. Though P. ramorum has been found in many different species in European nurseries, it has not yet been observed in the wild on any European species of oak [2,8]. The pathogen is believed to be an introduced species in both Europe and North America. Its home range is unknown, but there is some evidence that it may have originated in Asia [7,9].

Epidemiological studies have been conducted to identify areas that are most strongly affected by SOD and to assess the potential for spread into new locations $[10,11]$. These studies have concluded that there is a general area of high risk in the northwestern portion of California [11], and that P. ramorum primarily spreads from one host to another within $1 \mathrm{~km}$ [6]. The primary mechanism of spread appears to be through rain splash between infected and non-infected hosts [4]. There is no evidence that presence in surface water places nearby trees at risk of infection [6].

Two important factors in predicting the spread of P. ramorum are the range of temperature and moisture regimes that it can tolerate $[8,9,12]$. The pathogen will spread slowly in areas where the ambient temperature frequently exceeds or drops below the natural climate range to which it is adapted and will be unable to establish in areas that otherwise have suitable hosts due to inhospitable climate. It is difficult to assess the climatic tolerance of $P$. ramorum because the range of climate zones that it occupies natively remains unknown [4]. When predicting the potential range of the pathogen, researchers must consequently rely on environmental niche modeling based on the current observed geographic range of the pathogen on the West Coast or laboratory tests of P. ramorum to determine the range of meteorological conditions it can survive in a controlled environment $[8,9,13]$.

Previous studies have used different methods and come to divergent conclusions about the potential range of P. ramorum in the eastern United States. Venette and Cohen [12] used a combination of observations of P. ramorum and related Phytophthora organisms to generate a map of potential range. According to their analysis, the most favorable area for establishment of the pathogen would be the 
southern coastal area of Louisiana, Mississippi, and Alabama. The favorable climatic zone extends through the Florida panhandle (but not the peninsula), all the way up the Atlantic coast, west a short distance into Texas and Oklahoma, and north to just above the Ohio River, which roughly bisects the eastern United States [12]. Based on laboratory data collected by Tooley et al. [13] about P. ramorum's ability to survive different temperatures and soil moistures, Ireland et al. [8] found a more northerly possible range. They estimated a climatically favorable area centered around West Virginia, with a southern boundary at the southern end of the Appalachian Mountains and a northern boundary at the southern tips of Lakes Michigan, Erie, Huron, and Ontario. The eastern and western boundaries were at the Atlantic coast and at the boundary of the Great Plains, respectively $[8,13]$.

A further complication comes from the fact that climate is not likely to be stable over the next few decades. Under a warming climate scenario, the suitable range of $P$. ramorum could shift northward significantly as the severe winters that would damage the pathogen become rarer and rarer. Hotter summers could also contract the southern end of the climatically suitable range [14,15]. Additionally, a warming climate could affect the individual susceptibility of P. ramorum hosts to infection, a possibility that introduces further uncertainty into the understanding of the future climatic suitability of the eastern United States for SOD [15].

\subsection{Present Aims}

Efforts at delineation of suitable climate are useful, but do not address other important constraints on the distribution of P. ramorum in the eastern United States such as the presence of susceptible species and suitable host species to spread the disease; even in climates where P. ramorum can persist, there may be minimal impact on forest ecosystems if few susceptible species are present. This research aims to add an extra dimension by identifying the potential severity of P. ramorum invasion in eastern forests. The aim is to show not just where $P$. ramorum could potentially become established, but also to identify the potential change in forest composition given a hypothetical establishment. This information could be very useful for policy-makers and stakeholders to know where to target prevention efforts if SOD appears in the wild in the eastern United States.

Another goal for this research was to identify areas more suitable for P. ramorum at both large- and small-scales. We developed a large-scale index reflecting the overall suitability of the forest species composition for SOD based on the spatial juxtaposition of species that can contract and transmit P. ramorum. We also used network analysis to identify critical patches that may facilitate SOD spread in the Great Smoky Mountains National Park, which is located within a high-suitability region identified by our broader analysis. The large-scale index highlighted areas of the eastern United States where high potential for spread occurs in areas with high severity of disturbance resulting from SOD, while the network analysis identified locations through which P. ramorum is likely to spread if it becomes established in the Great Smoky Mountains.

\section{Materials and Methods}

\subsection{Study Area}

As it is not possible to predict where SOD will initially appear if it becomes established in eastern United States forests, all potential places in the eastern United States where P. ramorum could survive are worth examining. There are conflicting estimates of that potential range, so this study took a broad approach that examines the combination of all predicted ranges. This zone stretches along the majority of the Atlantic coast down to northern Florida and the northern coast of the Gulf of Mexico [12], west to the eastern portions of the North American Great Plains, and north to the southern tips of the southernmost Great Lakes, Michigan, Huron, Ontario, and Erie [8]. Our study range included all of the areas considered either at least "moderately suitable" by Ireland et al. [8] or at least "favorable" by Venette and Cohen [12], covering all areas that may be climatically suitable for the establishment of P. ramorum in the eastern USA (Figure 1). 


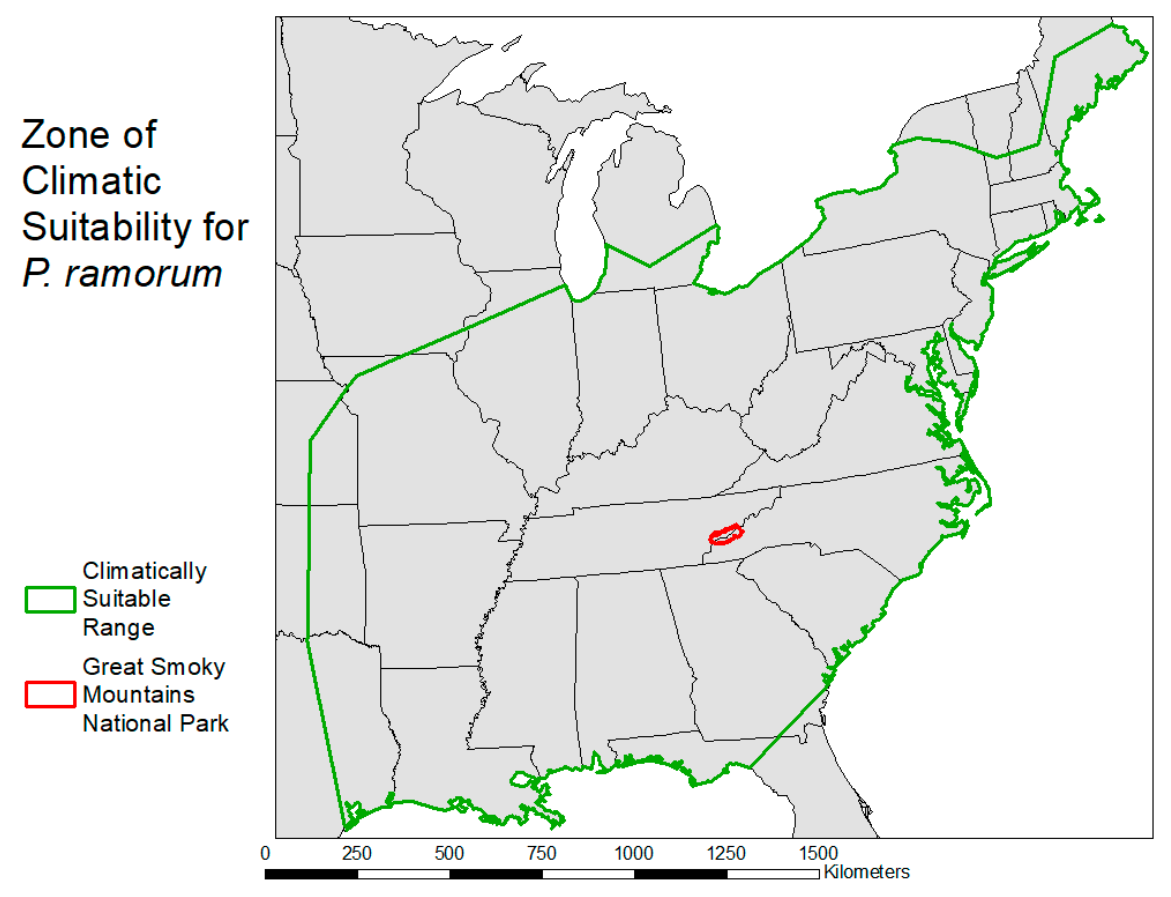

Figure 1. The green area represents the broad area of climatic suitability for P. ramorum in the eastern USA, combining the rough outlines of the suitable areas found by Ireland et al. [8] and Venette and Cohen [12]. The red area is the focal area used for the network analysis of P. ramorum spread.

The network analysis part of this paper focused on a portion of the southern Appalachians. Analysis of this small area provides a proof-of-concept, as separate stakeholders and policy-makers would be able to choose their own specific regions and perform the same analysis to get analogous results. The area chosen in this paper was the Great Smoky Mountains National Park on the Tennessee/North Carolina border (Figure 1). This region is marked as particularly susceptible by both Venette and Cohen [12] and Ireland et al. [8] and is heavily forested, meaning that there is a high risk of both the establishment of P. ramorum in the area and of environmental devastation should it become established. The severity map that we generated also identified the Great Smoky Mountains area as at particularly high risk.

\subsection{Severity Map}

We generated a map of potential P. ramorum disturbance severity in the eastern USA. This map displayed the percent of woody basal area (BA) that would be expected to be lost within ten years of the first presence of $P$. ramorum in the area.

Creating this map required identifying the presence of tree species that could be killed by P. ramorum. Abundances of at-risk tree species were measured using a raster dataset of live tree BA of the most common tree species across the contiguous USA [16]. This dataset, created by Wilson et al. [16], is based on satellite imagery, environmental variables including slope and soil characteristics, and field plots from the USA Forest Service's Forest Inventory and Analysis Program (FIA) [17,18], which takes regular field surveys across the USA at undisclosed plot locations to determine forest composition. The basal area of tree species was predicted using a gradient nearest neighbor technique incorporating the aforementioned environmental variables along with satellite-derived vegetation index values and field measurements from FIA plots [16,19]. The model produced a separate raster layer for each species composed of 250-m resolution cells with a value expressing the BA of a given species in square feet per acre in that area. The 2000-2009 based dataset was the most recent such estimate to be published, and we assumed that there were no major shifts in tree species distributions between 2009 and 2020. The tree species in the Wilson et al. [16] dataset were sorted into three categories (Table 1) 
based on whether they were known to be affected by P. ramorum [20,21]. These categories were as follows. (1) Susceptible-species that are known to be infected by P. ramorum and can be killed by it; these species are limited to oaks and larches (Larix) [22]. (2) Spreader-species that are known to be infected by P. ramorum and may be able to spread the pathogen on to other plants but which are not necessarily severely affected themselves. (3) Unaffected-species from genera that are not known to be infected by P. ramorum. For the purposes of this analysis, if one species from a common genus (Acer for instance) is known or strongly suspected to be a vector, all species in the genus were labeled as spreaders since it is likely that closely related species are capable of being infected and infection has simply not yet been observed in them. This reasoning did not apply to oaks, since it is generally agreed that white oaks are not highly susceptible, while red oaks are [4]. Notholithocarpus and Larix, which are both severely affected themselves and may also be able to transmit the infection, are included as both "susceptible" and "spreaders." This classification is not a definitive list of species affected by $P$. ramorum, as the susceptibility of many tree species is currently unknown. Additionally, many plant species not typically considered trees such as shrubs in the genera Rhododendron and Viburnum are also capable of spreading the pathogen. There is currently a lack of broad-scale geospatial data on the abundances of these species, meaning they cannot be included in this analysis.

Table 1. Tree genera and subgenera known to include suitable hosts for P. ramorum. "Susceptible" genera are those which are frequently killed by P. ramorum, while "spreader" genera are those that can be infected and pass on the pathogen. Some genera are in both categories.

\begin{tabular}{cc}
\hline Susceptible & Spreader \\
\hline & Abies-Fir \\
Pseudotsuga-Douglas Fir \\
Sequoia-Redwood \\
Acer-Maple \\
Aesculus-Buckeye \\
Arbutus-Madrone \\
Castanea-Chestnut \\
Cercis-Redbud \\
Cornus-Dogwood \\
Eucalyptus-Eucalyptus \\
Fuercus s. Lobatae-Red Oaks \\
Notholithocarpus-Tanoaks \\
Larix-Larch \\
\\
Fraxinus-Ash \\
Magnolia-Magnolia \\
Prunus-Cherry/Plum/Peach \\
Cinnamomum-Camphor tree \\
Salix-Willow \\
Umbellularia-California Laurel \\
Notholithocarpus-Tanoaks \\
Larix-Larch
\end{tabular}

All species in each of these three classes were summed to create raster layers of total BA in square feet per acre. The susceptible BA was then divided by the total BA of all species to get a proportion of total BA susceptible to P. ramorum per cell. This value provides an estimate of the proportion of canopy cover that could be destroyed by P. ramorum. From this proportion and from an assumed mortality rate of around 3\% per year for susceptible trees within range of infection [3], the expected percentage of trees that would die within a ten-year window from the initial presence of $P$. ramorum spreading within range of a given cell can be calculated by the formula:

$$
1-(1-m)^{10}
$$

where $m$ is the annual mortality probability taken roughly from the mortality probability for oaks according to McPherson et al. [3]. 


\subsection{Habitat Suitability Map}

To better understand the suitability of eastern USA forests for SOD, it is necessary to assess not just the possible severity that an invasion could have, but also the potential for spread in particular areas of forest. We assessed the potential for spread of SOD by incorporating information about spreader species at different scales. We note that most instances of spread have been documented in nursery settings, and it is not known whether all potential spreader species are capable of transmitting P. ramorum in wildland settings. Therefore, our mapping of spreader species should not be interpreted as a precise estimate of transmission potential and is based on the assumption that areas with high abundances of potential spreader tree species are most likely to have one or more species capable of spreading the disease.

We developed a habitat suitability index that incorporated information about the local abundance of susceptible species and the abundance of spreader species in the surrounding landscape. This was a combination of a ranking of the BA of susceptible species within a raster cell and a focal average of the BA of spreader species within $1 \mathrm{~km}$ of the cell. Susceptible species BA was calculated across the study area as one variable and spreader species BA as another. Both variables were reclassified from BA to an index from 0-3, then these scores were summed to compute the final composite index. For both spreader and susceptible species, the classification was the same. The cutoff points between index values were subjectively chosen to create classes that spanned the overall range of basal area values observed throughout the eastern USA (Table 2). The two indices were summed to obtain a total suitability index, though if either the susceptible BA or spreader BA scored a 0 , then the total index also scored a 0 . This is because if a section of forest has either no susceptibility or no chance for spread, then it is assumed that there is little chance for damage to the forest. Therefore, overall scores of 1 did not exist in the risk index.

Table 2. Index scores associated with given basal area (BA) ranges. The same classification was used for both the spreader species index and the susceptible species index.

\begin{tabular}{cc}
\hline BA Range & Associated Index Score \\
\hline BA $\leq 0.1 \mathrm{ft}^{2} /$ acre $\left(0.022 \mathrm{~m}^{2} / \mathrm{ha}\right)$ & 0 \\
$0.1 \mathrm{ft}^{2} /$ acre $\left(0.022 \mathrm{~m}^{2} / \mathrm{ha}\right)<\mathrm{BA} \leq 10 \mathrm{ft}^{2} /$ acre $\left(2.2 \mathrm{~m}^{2} / \mathrm{ha}\right)$ & 1 \\
$10 \mathrm{ft}^{2} /$ acre $\left(2.2 \mathrm{~m}^{2} / \mathrm{ha}\right)<\mathrm{BA} \leq 25 \mathrm{ft}^{2} /$ acre $\left(5.7 \mathrm{~m}^{2} / \mathrm{ha}\right)$ & 2 \\
$\mathrm{BA}>25 \mathrm{ft}^{2} /$ acre $\left(5.7 \mathrm{~m}^{2} / \mathrm{ha}\right)$ & 3 \\
\hline
\end{tabular}

Both groups were included in the risk index because the susceptible BA indicates where higher disturbance severity is possible and the spreader BA indicates where more trees that might be able to transmit the infection to susceptible species are present. The focal average of spreader species was used because the spread distance of P. ramorum is roughly one kilometer [6] (though spread of up to four kilometers has, on rare occasion, been recorded [23]), so all spreader species within a kilometer of a susceptible tree affect that tree's chances of becoming infected. Both the potential severity map and the SOD suitability map were generated using ArcGIS.

\subsection{Connectivity Analysis}

A connectivity analysis of patches of spreader species was used to examine how SOD could spread from location to location once established in a particular area. This connectivity analysis creates a network of patches, with connections between patches determined by the distance between them. Based on these connections, we calculated the "betweenness centrality" of each patch in the study area. Betweenness centrality is a measure of the importance of a particular patch in a network based on the number of shortest paths between other patches that pass through it. In this way, we were able to determine the relative importance of a patch for the overall hypothetical spread of $P$. ramorum through the study area. The study area selected was the Great Smoky Mountains National Park in the southern Appalachians, a place identified by multiple researchers as highly climatically favorable 
for P. ramorum [8,12]. The Great Smoky Mountains National Park has an area of 209,000 hectares. Patches for this analysis were identified as areas with a density of spreader species above a threshold of 50 square feet per acre (11.4 square meters per hectare), which was determined using the Jenks Natural Breaks method.

The connectivity network was created using the Linkage Mapper Package for ArcGIS [24]. This assumed a maximum spread distance of one kilometer to identify connections among patches of spreader species [6]. This is a simplification, given that spread farther than $1 \mathrm{~km}$ is occasionally possible [23], but we ignored such long-distance spread as an anomalous event. Connections were measured based on the shortest edge-to-edge distance between patches. Critical patches were those with a high betweenness centrality, a common method for identifying critical habitat patches in ecology [25]. High betweenness patches are the ones that $P$. ramorum are most likely to pass through as it spreads through a region, and thus may be important targets for control efforts. Additionally, we divided the betweenness of each patch over its area in hectares to get a value reflecting the relative importance of each patch to its size. Betweenness centrality values were calculated using the betweenness function in the igraph package for $\mathrm{R}[26,27]$.

\section{Results}

\subsection{Severity Map}

In the severity map (Figure 2), several areas stand out as being particularly susceptible to P. ramorum invasion. The Ozarks of southern Missouri and northern Arkansas in the south-central USA had a notably high potential severity due to the prevalence of oaks in these forests. This region sits just inside the edge of the climatically favorable region [8,12], meaning that P. ramorum could become established in this region. Southern New England in the northeastern USA also has a high potential severity of forest degradation. Another region with high potential severity (though lower than the Ozarks and New England) is the southern Appalachians, in the southeastern USA. Note that high potential severity areas do not necessarily have the densest forest cover. Severity may still be high in sparsely tree-covered areas if a large portion of what is there is composed of susceptible species.

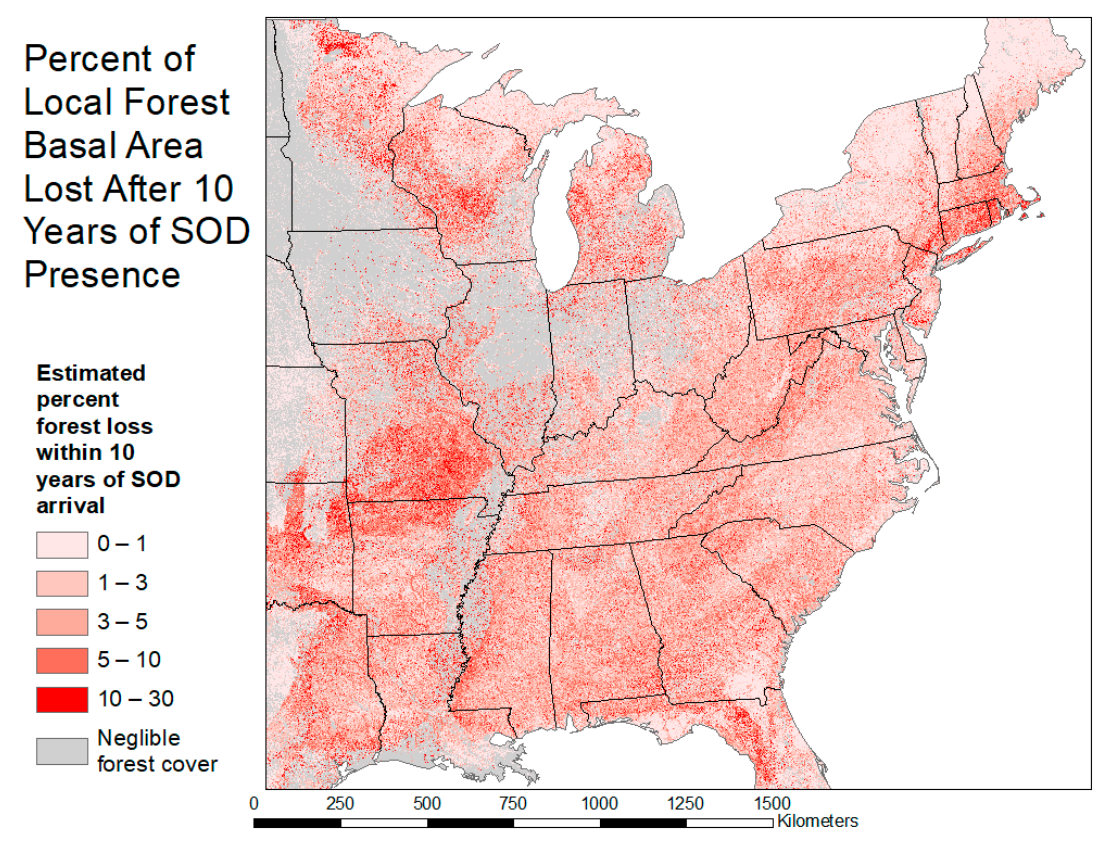

Figure 2. Estimated percentage of forest BA (assumed a proxy for canopy cover) lost within ten years of arrival of P. ramorum in the eastern USA. Resolution: $250 \mathrm{~m}$. 


\subsection{Habitat Suitability Map}

The habitat suitability analysis summed the index for susceptible species (Figure 3) and the index for spreader species (Figure 4) to create the combined risk index (Figure 5). Ultimately, a total of 18,479 square kilometers within the previously identified climatically suitable zone rated the highest habitat suitability score of six. The southern Appalachians, previously identified as highly climatically suitable $[8,12]$, also stood out as high on the habitat suitability index because there was both a high concentration of susceptible species and of spreader species in the area. Habitat suitability was also high in the northeast, particularly the far northeast, which was on the border of the climatically suitable area. Habitat suitability was comparatively much lower in the flatter southeastern coastal regions between the Appalachians and the ocean. In these areas, susceptible and especially spreader species BAs were lower than in areas of higher habitat suitability. Values of this suitability index were highly spatially heterogeneous, on both a macro- and meso-scale. The southern Appalachians, for instance, spanned the entire range of risk index values over just a few kilometers, reflecting changes in tree species composition and forest density with differing topographic setting (Figure 6). As noted earlier, the southern Appalachians fall within the climatically suitable zone, so areas with a high habitat suitability index are potentially prone to infections of P. ramorum.

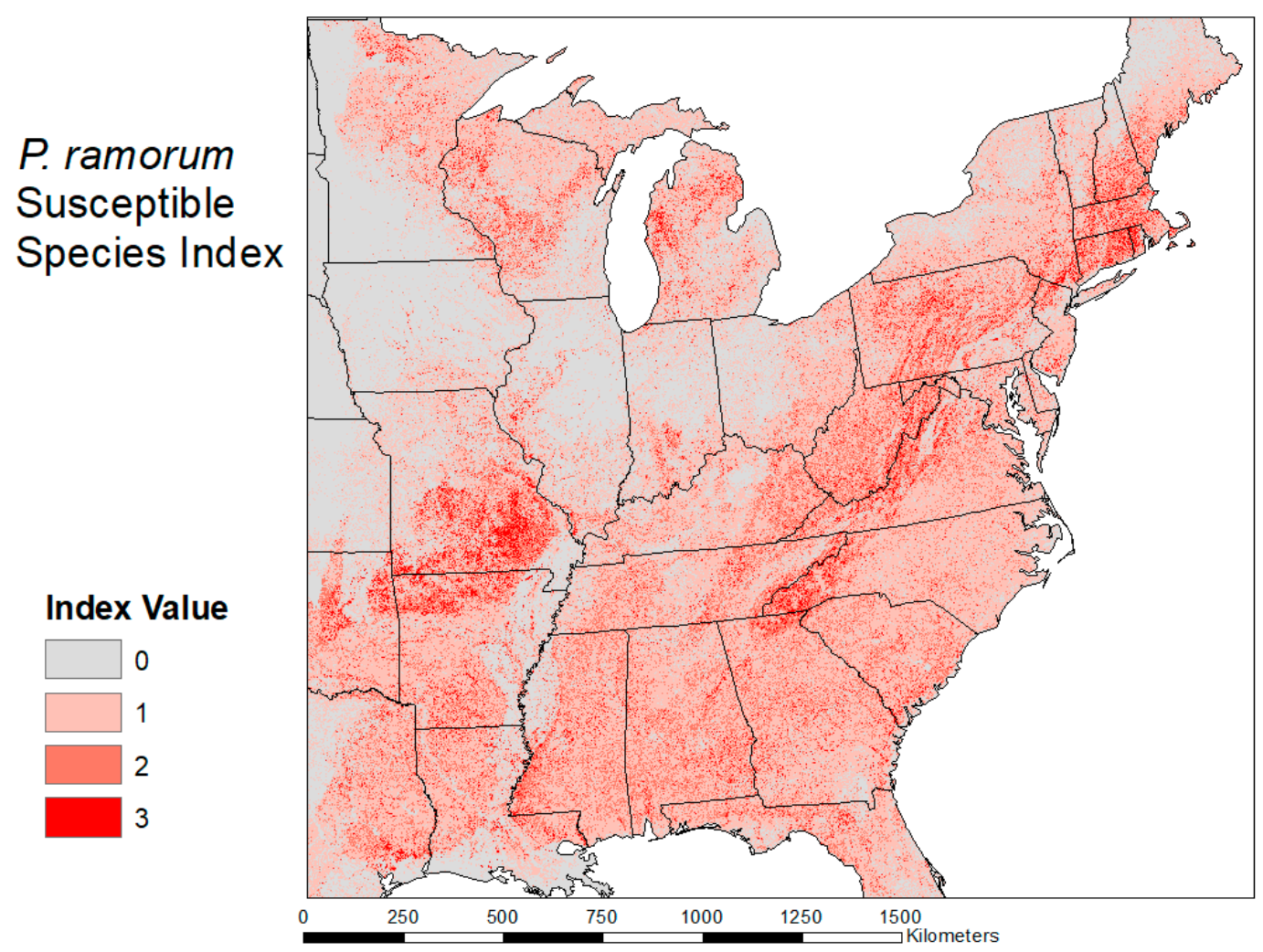

Figure 3. The index based on BA of tree species that can develop Sudden Oak Death (SOD). Resolution: $250 \mathrm{~m}$. 


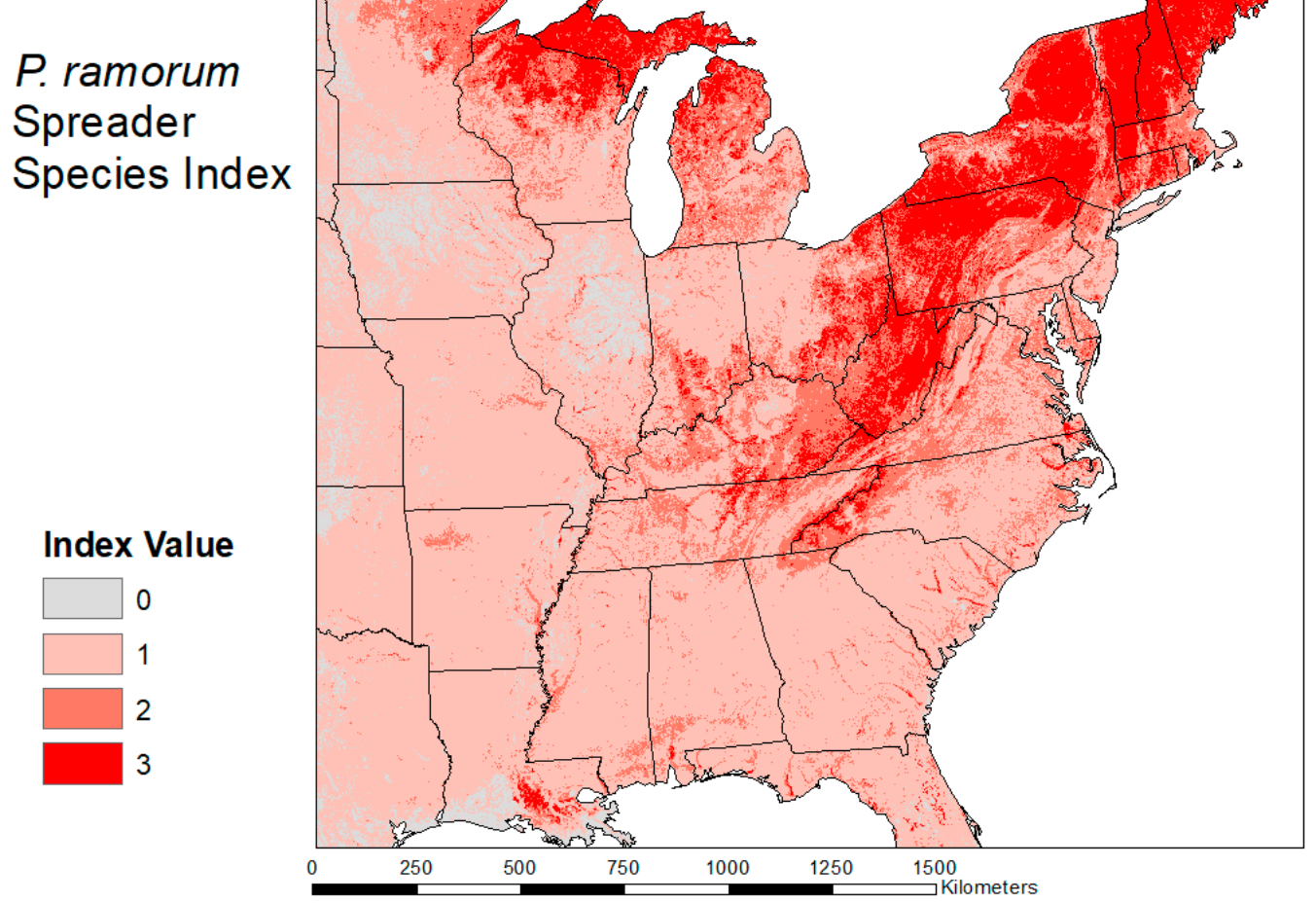

Figure 4. The index based on BA of P. ramorum spreader species. Resolution: $250 \mathrm{~m}$.

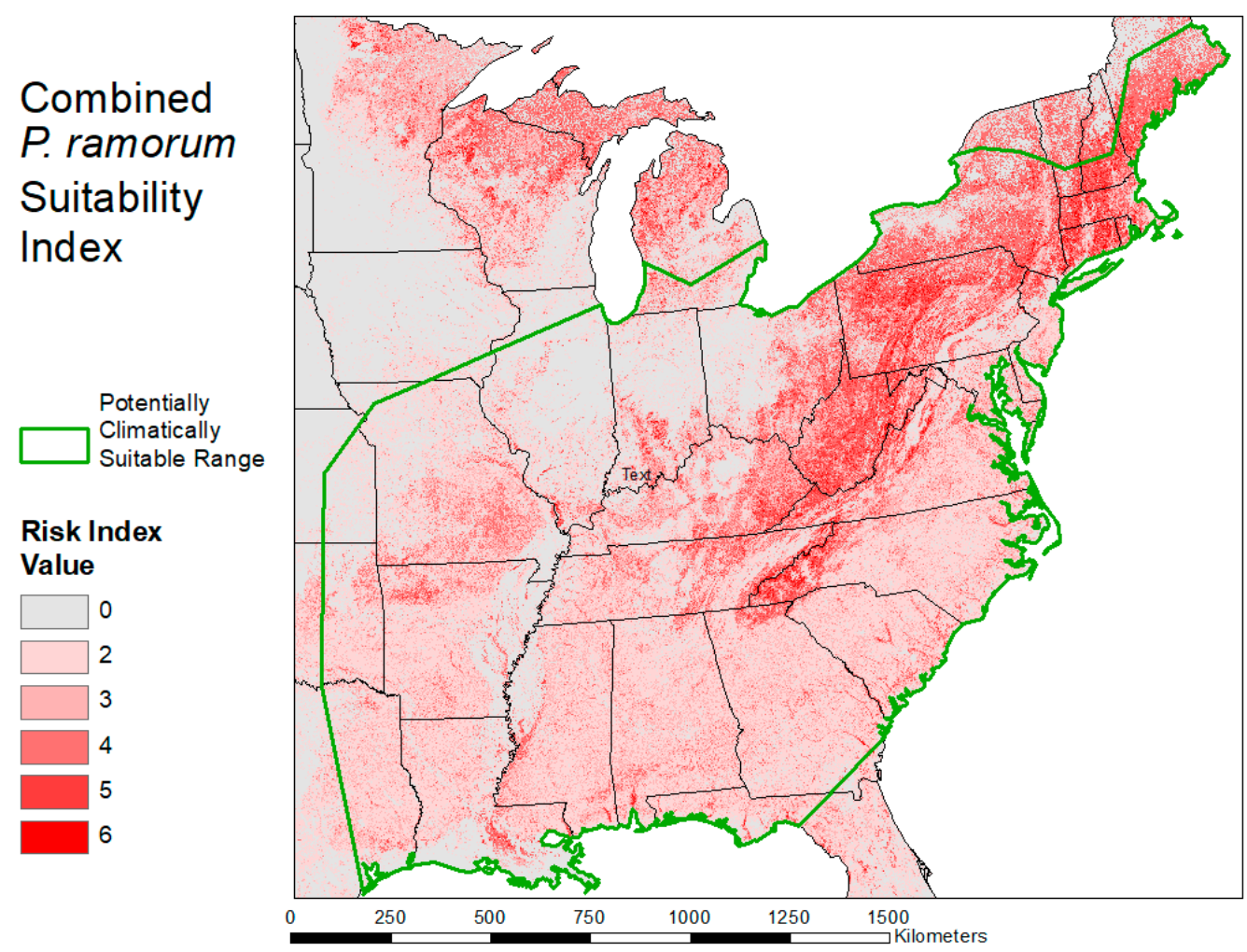

Figure 5. Combined index based on both susceptible and spreader species. Higher numbers indicate higher overall levels of host suitability. A score of zero indicates an insignificant number of either spreader or susceptible species, meaning that there is no risk of forest cover loss. Resolution: $250 \mathrm{~m}$. 


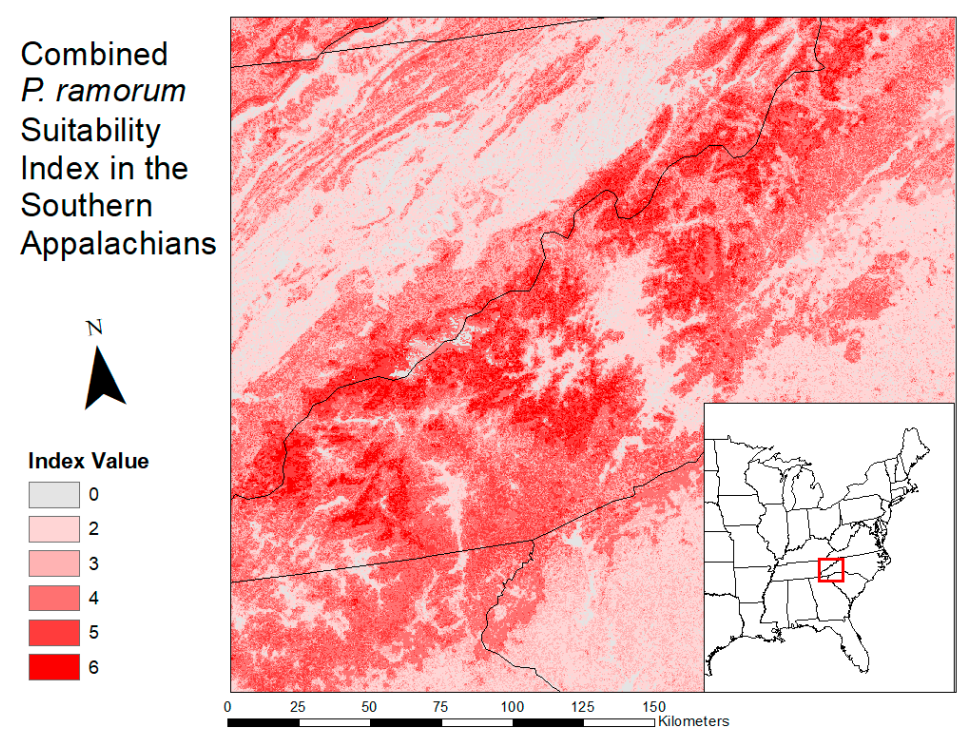

Figure 6. Combined index values within the specific context of a highly suitable area in the southern Appalachians. Resolution: $250 \mathrm{~m}$.

\subsection{Connectivity Analysis}

We used network modeling to determine the areas of forest that were most likely to facilitate spread at a landscape scale within the Great Smoky Mountains National Park. Patches were determined to be those areas of forest with a density of spreader species BA greater than 50 square feet per acre. These patches were considered linked if they were within one kilometer of one another (Figure 7). Every patch with a high density of spreader species had its level of connectedness measured with a "betweenness centrality" value (Figure 8). Betweenness values were highly skewed to the right; most patches had a betweenness value of close to zero, while a few patches had large values up to the hundreds of thousands. The median betweenness value was 94.7. Many of the large patches, particularly the largest patch in the center, had higher betweenness values than smaller patches due to their high numbers of connections to adjacent patches.

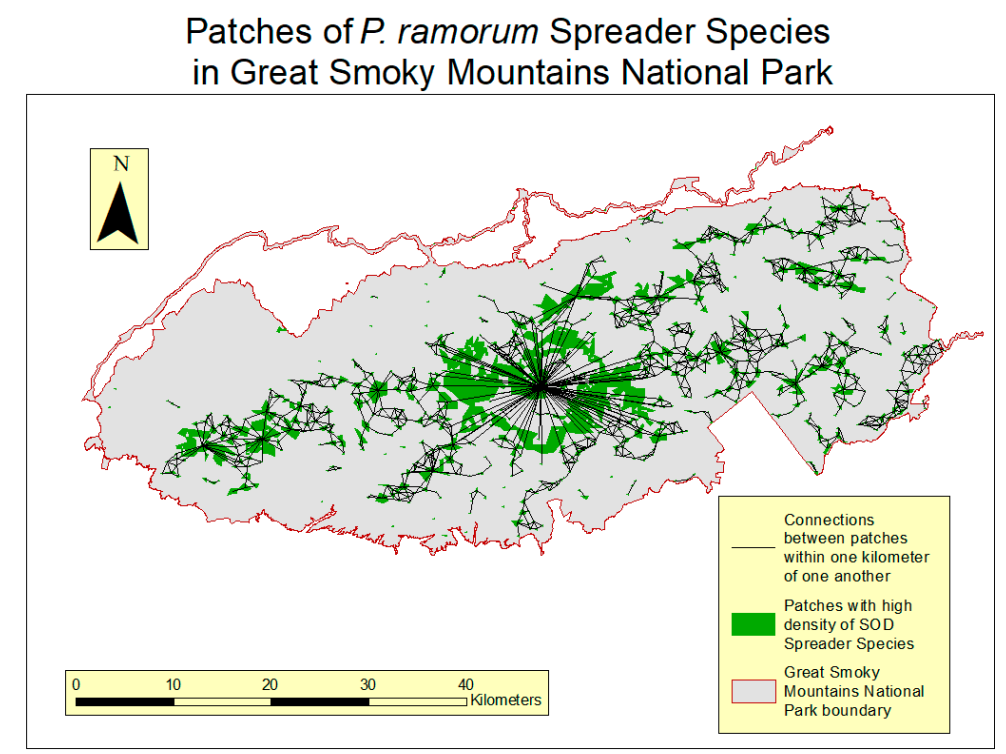

Figure 7. Patches with very high density of spreader species for P. ramorum in the Great Smoky Mountains National Park. Black lines connect the centroids of patches where edge-to-edge distance is less than $1 \mathrm{~km}$. 


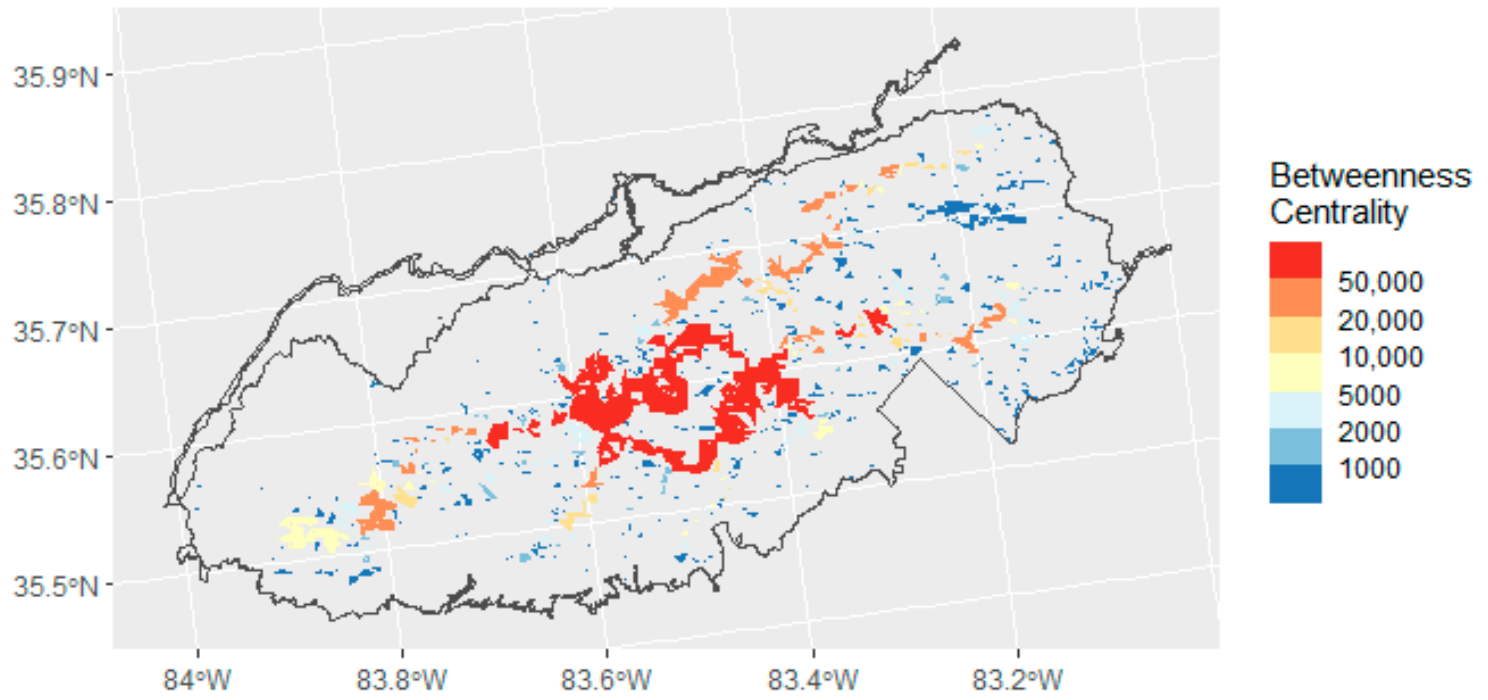

Figure 8. Betweenness centrality of patches dominated by SOD spreader species in the Great Smoky Mountains National Park.

To gain more insights into the relative importance of small patches for disease spread, the betweenness centrality divided by area (in square meters) was also computed for each patch (Figure 9). This index yields an indicator of the importance of individual patches relative to their size. Most small patches had relatively low values. The few patches with larger values were smaller patches located closer to the center of the park that appeared to provide connectivity between other groups of patches.

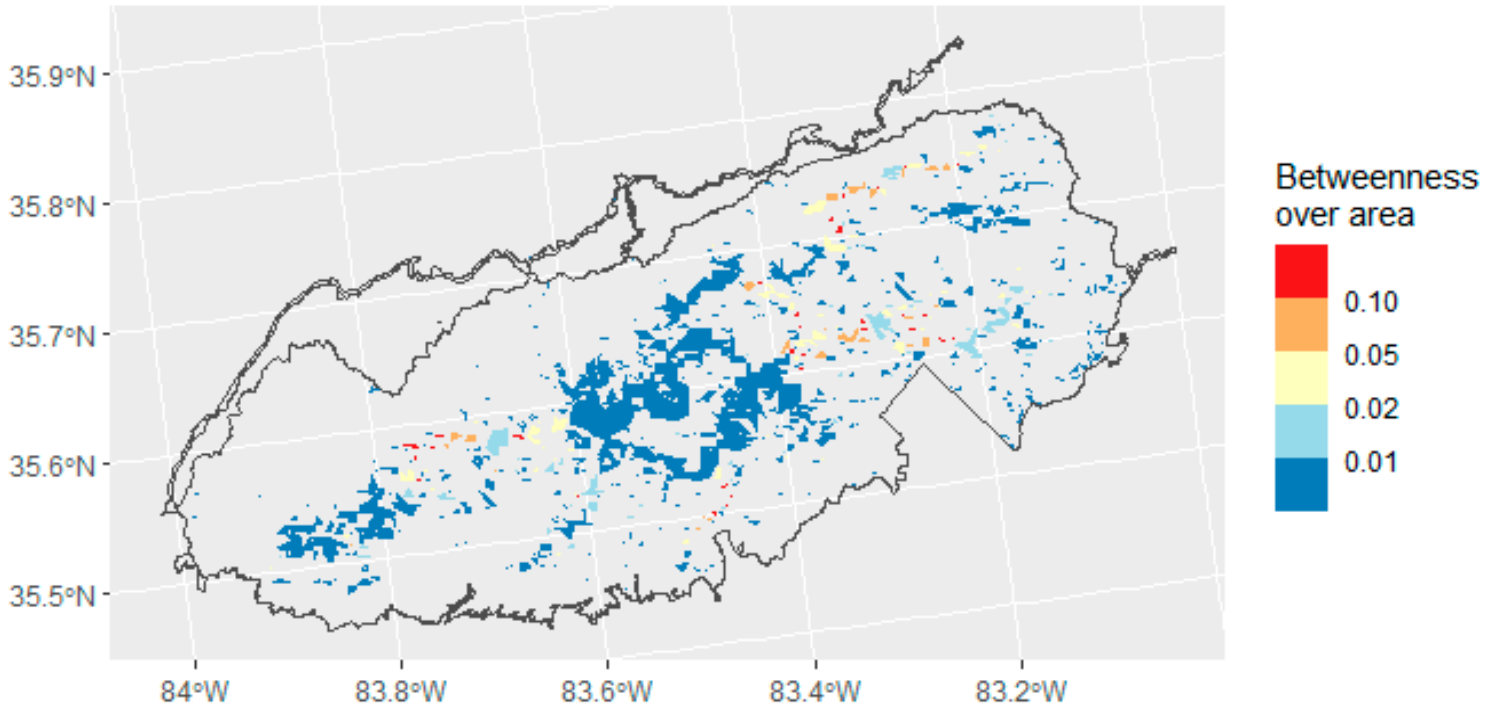

Figure 9. Betweenness centrality divided by area (in square meters) for patches dominated by SOD spreader species in the Great Smoky Mountains National Park.

\section{Discussion}

Results from this analysis highlighted the possibility of widespread damage in forests of the eastern USA caused by SOD. Based on the severity map (Figure 2), the majority of the eastern forest would lose more than $1 \%$ of its tree BA within ten years of the arrival of $P$. ramorum in that area. Many areas could lose much more, up to $30 \%$ in particularly vulnerable areas like the Ozarks. This level of tree mortality would have serious environmental repercussions. Not only would these losses reduce the quality of forest habitat, but if red oak species become rare or nonexistent, species that depend on 
them could also be harmed. For instance, the black bears of the southern Appalachians, which depend on red oak acorns for a large part of their caloric intake [28], could struggle to find enough food to sustain themselves through winter hibernation. Economic losses could also occur as timber resources become scarcer. While red oaks make up a declining share of USA lumber production, they are still important to several sub-industries. For instance, as of 2017, 35\% of USA hardwood plywood production comes from red oak [29].

The only way it would be possible for P. ramorum to disturb forests in the eastern USA is if it can survive in the climate of the eastern USA. While predictions of climatic suitability vary, most studies suggest SOD could become established in at least parts of the eastern USA, particularly the Appalachians $[8,9,12]$. These areas are topographically diverse and have considerable variation in microclimates, and there is almost certainly more fine-scale variability in climate suitability for $P$. ramorum [30]. As suitable hosts are also widespread in the eastern USA, it is almost certain that some areas are at risk for the establishment of $P$. ramorum in the wild. Furthermore, climate change may make it possible for $P$. ramorum to survive in some areas that are not currently suitable, or it may make summers too hot for P. ramorum in areas that are currently suitable, or even affect the individual susceptibility of hosts to infection $[14,15]$.

As mentioned earlier, there is a lack of consensus on the exact level and range of climatic suitability of the eastern USA for P. ramorum [8,12]. This adds further uncertainty about the potential effects of SOD in the region. Our model does not account for geographic variations in climate and thus assumes uniform climatic suitability across the study region. In reality, complex patterns of climate across space and time would produce varying results in the potential for SOD to become established, spread, and cause forest damage. This model should therefore not be interpreted as a precise estimate of risk of SOD establishment. Instead, it provides an initial assessment of the potential variation in suitability for $P$. ramorum arising from variation in forest species composition, assuming climatic suitability on a level relatively similar to that of California, where the disease has been best studied. This is not likely to be true across the entire region, as the climate of the eastern USA is quite varied and different from that of California. With these caveats in mind, the results presented herein can still provide useful information about geographic variation in the potential impacts of P. ramorum introduction.

Disturbance caused by SOD could be analogous to that caused by other Phytophthora species, which often leads to similar symptoms. P. cinnamomi was responsible for significant damage to oak forests in Iberia [31] as well as the jarrah dieback outbreak in Australia, which has completely destroyed some areas of forest [2]. A North American analog would be the chestnut blight, caused by Cryphonectria parasitica, which eliminated an important tree species from the eastern USA forests [32]. To avoid a similar extirpation of oak species, policy makers and stakeholders should be prepared to take steps to slow the spread of P. ramorum should it arrive in the forests of the eastern USA. These efforts might include thinning of spreader species, which a simulation model-based analysis found to be highly effective at limiting the spread of P. ramorum [5].

Overall risk to the forest from SOD depends on both the degree of susceptibility to it and the ability of the pathogen to spread into an area through spreader species. For this reason, we created a habitat suitability index by combining a ranking of the concentration of susceptible and spreader species across the eastern USA. The highest overall suitability for SOD occurs in areas where there are both high abundances of susceptible species that could be infected and killed and high abundances of spreader species that could allow P. ramorum to move into the area. As seen in Figures $2-5$, the areas with high overall suitability for SOD are not exactly the same as those with high potential severity of forest loss. Although the Ozarks had a high potential severity of tree loss, their overall suitability was lower than the Appalachians because of a lower abundance of spreader species.

A network analysis was used to highlight particular areas of importance to P. ramorum spread within the Great Smoky Mountains National Park, which was identified as a high-risk location. We found that a relatively small number of forest patches made a disproportionately large contribution to the spread of P. ramorum. Identifying these important patches may be useful for targeting monitoring 
and management activities. This method could be extended to other locations to identify particular areas through which SOD is likely to spread to move to new areas. Our approach differed from that used in a previous network analysis by Ellis et al. [33]. Their study assessed connectivity between field plot locations based on cost-weighted distance that accounted for the landscape patterns of host species [33]. We first defined patches as locations with high abundances of spreader species, and then measured connectivity with Euclidean distance because spreader species are assumed to be less common outside of these patches. The different approach used herein is more suitable as we had a different objective than Ellis et al. [33]. They intended to empirically test the importance of landscape dynamics by showing that connectivity had an effect on the chance that SOD would spread between two point locations [33]. In our study, we used a Euclidean distance-based network to identify the relative importance of particular patches to overall connectivity.

Overall, there is reason to suspect that SOD could become established in the eastern USA and cause damage to forests, as it has in California. Both spreader and susceptible species are abundant, and almost certainly at least some parts of the eastern USA are climatically suitable for P. ramorum $[8,9,12,13]$. Average spreader BA is considerably lower in the eastern USA than in the western USA, with a maximum of 40 square meters per hectare in New York State, compared to a maximum of 175 square meters per hectare in the redwoods area of northern California, though that may be because there are yet-unknown potential spreader species in the eastern part of the country. In any case, spreader species abundance is most likely high enough to support a P. ramorum population, as some identified infections on the edges of the current wild range in California exist in areas with lower concentrations of spreader species, similar to those seen in the eastern USA. However, it is possible that proper control efforts could limit the destruction caused by P. ramorum. Thinning of spreader species has been investigated in Oregon and California, and this as well as other methods of disease control have so far successfully contained P. ramorum to a small corner of the state of Oregon [5,6]. Given similar or even lower spreader species density in the eastern forests, it is plausible that these techniques would also work in the eastern USA.

Although this study was based on the best currently available data and knowledge about P. ramorum and the species composition of forests in the eastern USA, there are several important limitations. The geospatial data on tree species distributions were derived from a predictive model that interpolates in between forest inventory plot locations. Although the predictions were generally accurate at broad spatial scales [19], the uncertainty in these maps propagates through to our analyses. Additionally, we were not able to incorporate non-tree spreader species into the analysis because geospatial predictions were not available. Some of these species, like shrubs in the genus Rhododendron, are widespread in parts of the eastern USA and could influence the risk of SOD. Better quantitative data on the ability of tree and shrub species to transmit $P$. ramorum in wildland settings will also be needed to develop more precise estimates of the risk posed to forests in the eastern USA. Additionally, we did not consider differences in host susceptibility at any finer degree than the binary classification of hosts as "susceptible" and "spreader". In reality, levels of susceptibility may vary between susceptible species [3] or even within species due to genetic differences or climatic differences across space and time [14]. We also did not consider genetic differences between strains of $P$. ramorum, which may affect outcomes. Overall, our analysis provided a relatively straightforward assessment of potential suitability for SOD in the eastern USA based on currently available data, but we expect that it can and should be extended and improved as better information becomes available and more is learned about P. ramorum ecology.

\section{Conclusions}

SOD poses a serious threat to the forests of the eastern USA if the pathogen, Phytophthora ramorum, is able to establish and spread in this region. Previous research has found that large portions of the eastern USA are climatically suitable for $P$. ramorum, although the predicted geographic range varies depending on the methods used $[8,9,12,13]$. This study builds on these findings by examining the 
distributions of host tree species including susceptible as well as spreader species to identify locations within these climate envelopes where risk of SOD is the highest.

Certain areas such as the Ozarks face potentially more severe outbreaks than others due to a higher proportion of susceptible red oaks. However, overall suitability may be low in the Ozarks because of the low abundance of spreader species. The risk of SOD was found to be highest in parts of the Appalachians where there were substantial concentrations of susceptible species combined with high abundances of nearby spreader species. At a landscape scale, we found that a relatively small number of the patches of spreader species can have a disproportionately high importance for facilitating disease spread. Our model is limited by the fact that we did not incorporate climate variables into our model, as others have focused on this before. Consequently, the actual suitability for SOD of any given area may be different than what is presented here, which may be taken as a possible value, assuming climatic suitability comparable with that of California.

Taken as a whole, these results indicate that specific geographic locations can be identified based on species composition and targeted for activities such as monitoring and management in response to the threat of SOD. The results of this initial assessment should be refined and extended as better data on plant species distributions and more knowledge about $P$. ramorum ecology become available.

Author Contributions: Conceptualization, D.J.H.; Methodology, D.J.H. and M.C.W.; Software, D.J.H.; Formal analysis, D.J.H.; Investigation, D.J.H.; Data curation, D.J.H.; Writing-original draft preparation, D.J.H.; Writing-review and editing, D.J.H. and M.C.W.; Visualization, D.J.H. and M.C.W.; Supervision, M.C.W.; Project administration, D.J.H. All authors have read and agreed to the published version of the manuscript.

Funding: This research received no external funding.

Acknowledgments: The authors would like to acknowledge Thomas Neeson, of the University of Oklahoma, for his help in developing the initial idea for this research.

Conflicts of Interest: The authors declare no conflict of interest.

\section{References}

1. Davidson, J.M.; Werres, S.; Garbelotto, M.; Hansen, E.M.; Rizzo, D.M. Sudden oak death and associated diseases caused by Phytophthora ramorum. Plant Health Prog. 2003, 4. [CrossRef]

2. Rizzo, D.; Garbelotto, M. Sudden oak death: Endangering California and Oregon forest ecosystems. Front. Ecol. Environ. 2003, 1, 197-204. [CrossRef]

3. McPherson, B.A.; Mori, S.R.; Wood, D.L.; Kelly, M.; Storer, A.J.; Svihra, P.; Standiford, R.B. Responses of oaks and tanoaks to the sudden oak death pathogen after $8 \mathrm{y}$ of monitoring in two coastal California forests. For. Ecol. Manag. 2010, 259, 2248-2255. [CrossRef]

4. Grunwald, N.J.; LeBoldus, J.M.; Hamelin, R.C. Ecology and evolution of the sudden oak death pathogen Phytophthora ramorum. Annu. Rev. Phytopathol. 2019, 57, 301-321. [CrossRef] [PubMed]

5. Bussell, E.H.; Cunniffe, N.J. Ongoing surveillance protects tanoak whilst conserving biodiversity: Applying optimal control theory to a spatial simulation model of sudden oak death. J. R. Soc. Interface 2019, 17. [CrossRef]

6. Garbelotto, M.; Rizzo, D.M.; Meentemeyer, R.K.; Swiecki, T.; Owen, D.; Marshall, J.; Blomquist, C.; Bell, L.; Valachovic, Y. SODMap [Google Earth KMZ File]. 2019. Available online: https://nature.berkeley.edu/ matteolab/?page_id=755 (accessed on 6 November 2019).

7. Jung, T.; Pérez-Sierra, A.; Rees, H.; Scanu, B.; Bakonyi, J.; Seress, D.; Maia, C.; Harris, A.; Webber, J.; Brasier, C.; et al. Diversity of Phytophthora species in natural forests and streams and in rubber plantations in Vietnam. In Proceedings of the 8th Meeting of the International Union of Forestry Research Organizations, Phytophthora in Forests and Natural Ecosystems, Hanoi, Vietnam, 18-25 March 2017; IUFRO: Vienna, Austria, 2017; p. 56. Available online: https://www.iufro.org/fileadmin/material/publications/proceedings-archive/70209vietnam17-abstracts.pdf (accessed on 13 December 2020).

8. Ireland, K.B.; Hardy, G.E.S.J.; Kriticos, D.J. Combining inferential and deductive approaches to estimate the potential geographical range of the invasive plant pathogen, Phytophthora ramorum. PLoS ONE 2013, 8. [CrossRef]

9. Kluza, D.A.; Vieglais, D.A.; Andreasen, J.K.; Peterson, A.T. Sudden oak death: Geographic risk estimates and predictions of origins. Plant Pathol. 2007, 56, 580-587. [CrossRef] 
10. Mascheretti, S.; Croucher, P.J.; Kozanitas, M.; Baker, L.; Garbelotto, M. Genetic epidemiology of the sudden oak death pathogen Phytophthora ramorum in California. Mol. Ecol. 2009, 18, 4577-4590. [CrossRef]

11. Meentemeyer, R.K.; Cunniffe, N.J.; Cook, A.R.; Filipe, J.A.N.; Hunter, R.D.; Rizzo, D.M.; Gilligan, C.A. Epidemiological modeling of invasion in heterogeneous landscapes: Spread of sudden oak death in California (1990-2030). Ecosphere 2011, 2, art17. [CrossRef]

12. Venette, R.C.; Cohen, S.D. Potential climatic suitability for establishment of Phytophthora ramorum within the contiguous United States. For. Ecol. Manag. 2006, 231, 18-26. [CrossRef]

13. Tooley, P.W.; Browning, M.; Berner, D. Recovery of Phytophthora ramorum following exposure to temperature extremes. Plant Dis. 2008, 92, 431-437. [CrossRef] [PubMed]

14. Venette, R.C. Implication of global climate change on the distribution and activity of Phytophthora ramorum. In Proceedings of the 20th US Department of Agriculture interagency research forum on invasive species, Annapolis, MD, USA, 13-16 January 2009; McManus, K.A., Gottschalk, K.W., Eds.; USDA Forest Service: Newtown Square, PA, USA, 2009; pp. 58-59. Available online: https://www.nrs.fs.fed.us/pubs/gtr/gtr_nrs-p51.pdf (accessed on 13 December 2020).

15. Venette, R.C. Incorporating climate change into pest risk models for forest pathogens: A role for cold stress in an era of global warming? NeoBiota 2013, 18, 131-150. [CrossRef]

16. Wilson, B.T.; Lister, A.J.; Riemann, R.I.; Griffith, D.M. Live Tree Species Basal Area of the Contiguous United States (2000-2009); USDA Forest Service: Newtown Square, PA, USA, 2013. [CrossRef]

17. United States Forest Service. Forest Inventory and Analysis National Program. 2019. Available online: https://www.fia.fs.fed.us/ (accessed on 6 November 2019).

18. Bechtold, W.A.; Patterson, P.L. (Eds.) The enhanced forest inventory and analysis program-National sampling design and estimation procedures. In General Technical Reports; US Department of Agriculture, Forest Service, Southern Research Station: Asheville, NC, USA, 2005. [CrossRef]

19. Wilson, B.T.; Lister, A.J.; Riemann, R.I. A nearest-neighbor imputation approach to mapping tree species over large areas using forest inventory plots and moderate resolution raster data. For. Ecol. Manag. 2012, 271, 182-198. [CrossRef]

20. USDA-APHIS. APHIS List of Hosts and Plants Associated with Phytophthora ramorum. 2020. Available online: http://www.aphis.usda.gov/plant_health/plant_pest_info/pram/downloads/pdf_files/usdaprlist.pdf (accessed on 6 November 2019).

21. California Oak Mortality Task Force. Phytophthora ramorum Hosts Reported since 2012/2013 and Missing from the APHIS P. ramorum Host or Associated Host List. 2018. Available online: http://www.suddenoakdeath. org/wp-content/uploads/2018/10/P-ramorum-hosts-detected-since-2012.pdf (accessed on 17 July 2020).

22. Brasier, C.M.; Webber, J. Sudden larch death. Nature 2010, 466, 824-825. [CrossRef]

23. Hansen, E.M.; Kanaskie, A.; Prospero, S.; McWilliams, M.; Goheen, E.M.; Osterbauer, N.; Reeser, P.; Sutton, W. Epidemiology of Phytophthora ramorum in Oregon tan oak forests. Can. J. For. Res. 2008, 38, 1133-1143. [CrossRef]

24. McRae, B.H.; Kavanagh, D.M. Linkage Mapper Connectivity Analysis Software. The Nature Conservancy, Seattle United States. 2011. Available online: http://www.circuitscape.org/linkagemapper (accessed on 10 March 2020).

25. Wimberly, M.C.; Narem, D.; Bauman, P.; Carlson, B.; Ahlering, M. Grassland connectivity in fragmented agricultural landscapes of the north-central United States. Biol. Conserv. 2018, 217, 121-130. [CrossRef]

26. Csardi, G.; Nepusz, T. The Igraph Software Package for Complex Network Research. 2006. Available online: http://igraph.org (accessed on 17 April 2020).

27. R Core Team. R: A Language and Environment for Statistical Computing (3.6.3). 2020. Available online: https://www.R-project.org/ (accessed on 19 March 2020).

28. Inman, R.M.; Pelton, M.R. Energetic production by soft and hard mast foods of American black bears in the Smoky Mountains. Ursus 2002, 13, 57-68. Available online: https: //www.bearbiology.org/publications/ursus-archive/energetic-production-by-soft-and-hard-mast-foods-ofamerican-black-bears-in-the-smoky-mountains/ (accessed on 13 December 2020). 
29. Howard, J.L.; Liang, S.U.S. timber production, trade, consumption, and price statistics. 1965-2017. In Res. Pap. FPL-RP-701; U.S. Department of Agriculture, Forest Service, Forest Products Laboratory: Madison, WI, USA, 2019; pp. 1-106. Available online: https://www.fs.usda.gov/treesearch/pubs/58506 (accessed on 8 November 2020).

30. Fridley, J.D. Downscaling climate over complex terrain: High finescale $(<1000 \mathrm{~m})$ spatial variation of near-ground temperatures in a montane forested landscape (Great Smoky Mountains). J. App. Meteorol. Climatol. 2009, 48, 1033-1049. [CrossRef]

31. Brasier, C.M.; Scott, J.K. European oak declines and global warming: A theoretical assessment with special reference to the activity of Phytopthora cinnamomi. EPPO Bull. 1994, 241, 221-232. [CrossRef]

32. Anagnostakis, S. Chestnut blight: The classical problem of an introduced pathogen. Mycologia 1987, 79, 23-37. [CrossRef]

33. Ellis, A.M.; Vaclavik, T.; Meentemeyer, R.K. When is connectivity important? A case study of the spatial pattern of sudden oak death. Oikos 2010, 119, 485-493. [CrossRef]

Publisher's Note: MDPI stays neutral with regard to jurisdictional claims in published maps and institutional affiliations.

(C) 2020 by the authors. Licensee MDPI, Basel, Switzerland. This article is an open access article distributed under the terms and conditions of the Creative Commons Attribution (CC BY) license (http://creativecommons.org/licenses/by/4.0/). 